\title{
KAJIAN LINGUISTIK FUNGSIONAL SISTEMIK PADA PEMBERITAAN KEKERASAN GENDER DALAM MEDIA CETAK LOMBOK POST DAN RELEVANSINYA TERHADAP PEMBELAJARAN WACANA DI PERGURUAN TINGGI
}

\section{(SYSTEMIC FUNCTIONAL LINGUISTIC ANALYSIS OF GENDER VIOLENCE IN PRINT MEDIA LOMBOK POST AND IT'SRELEVANCE TOWARD DISCOURSE LEARNING IN COLLEGE)}

\author{
Irma Setiawan, Muhammad Sukri \\ Universitas Mataram \\ Jalan Majapahit Nomor 62, Komplek Kampus FKIP Unram \\ Gedung A, Lantai 1 Mataram, NTB, Indonesia 83125 \\ Pos-el: irmasetiawan9@gmail.com; sukrimuhammad75@gmail.com
}

Diterima: 30 Januari 2014; Direvisi: 13 Oktober 2014; Disetujui: 24 Oktober 2014

\begin{abstract}
Gender violence is a contemporary issue often discussed by the community in social interactions. In this case, the form of gender violence more easily found in the news media text with a variety of cases, such as: marriage, divorce, rape, molestation or sexual abuse, assault, robbery, sexual gratification or prostitution, and even murder motivated revenge romance. Therefore, the purpose of this study is to describe the representation of gender violence through transitivity system, modalities, and its relevance to discourse study in the university as well. The theory which is used in this study is the theory LFS presented by Halliday in which it focuses on the text, in this case the text of gender violence in the media. Data collection are performed by the method of literature analysis and note-taking. Sources of data obtained only on the text of gender violence in the media Lombok Post news. The collected data were analyzed by using both qualitative and quantitative method. The intended of those methods are to describe the research systematically, well organized, and patterned. The results of data analysis showed are domination of male's action toward women in cases of domestic violence and non-domestic violence in the NTB area which had previously been analyzed through the system of transitivity and modality system. Women are more often represented as victims, whereas men often positioned as the doer in the act of gender violence, therefore the women are the aggrieved object in the cases of domestic violence and non-domestic violence.
\end{abstract}

Keywords: gender violence, text, media, LFS, and learning

Abstrak

Kekerasan gender ialah isu kekinian yang marak diperbincangkan media dalam interaksi sosial di masyarakat. Beragam bentuk kasus kekerasan gender kian sering ditemukan pada teks pemberitaan media cetak, seperti; perkawinan, perceraian, pemerkosaan, pencabulan atau pelecehan seksual, penganiayaan, perampokan, gratifikasi seks atau prostitusi, dan bahkan pembunuhan bermotif dendam asmara. Permasalah pada penelitian ini terfokus pada analisis transitivitas dan modalitas pada pemberitaan kekerasan gender dan relevansinya terhadap pembelajaran wacana diperguruan tinggi. Sejalan dengan itu, tujuan penelitian ini berupaya mendeskripsikan representasi kekerasan gender melalui sistem transitivitas dan modalitas serta relevansinya terhadap pembelajaran wacana di perguruan tinggi. Teori yang 
dipergunakan dalam penelitian ini, yakni teori LFS oleh Halliday yang berfokus pada teks, dalam hal ini teks kekerasan gender di media. Pengumpulan data dilakukan dengan metode pustaka dengan teknik baca dan teknik catat. Sumber data hanya diperoleh pada teks pemberitaan kekerasan gender di media Lombok Post. Data yang terkumpul dianalisis dengan metode kombinasi, yakni deskriptif kualitatif dan kuantitatif guna mendeskripsikan penelitian secara sistematis, kategorisasi, dan terpola. Hasil penelitian ini berupa dominasi tindakan lakilaki terhadap perempuan dalam kasus KDRT dan Non-KDRT di wilayah NTB yang sebelumnya telah dianalisis melalui sistem transitivitas dan sistem modalitas. Perempuan lebih sering ditampilkan sebagai korban, sedangkan laki-laki kerap diposisikan sebagai pelaku tindakan dalam kekerasan gender, sehingga pihak perempuan (adalah objek yang dirugikan) dalam kasus KDRT dan Non-KDRT.

Kata kunci: kekerasan gender, teks, media, LFS, dan pembelajaran.

\section{Pendahuluan}

Isu kekerasan gender dalam pemberitaan media massa merupakan isu sensitif yang terjadi dalam kehidupan masyarakat Indonesia, terutama masyarakat di NTB. Tingkat kekerasan dan pelecehan seksual pada anak-anak dan perempuan semakin hari kian akut di tengah kampanye pemerintah tentang gerakan anti-kekerasan terhadap anakanak dan perempuan. Lebih dari itu, ketidakharominasan interaksi perempuan dan laki-laki kerap dinodai dengan insiden memilukan, seperti pembunuhan sadis dalam keluarga, perceraian, jumlah janda yang semakin banyak, pelecehan seksual, pencabulan anak di bawah umur, anak-anak terlahir tanpa ayah dan ibu, dan masih banyak kasus lainnya.

Berdasarkan data Komisi Nasional Anti Kekerasan Terhadap Perempuan (2009:9); (2010:9); (2011:8); (2012:18); (2013:34) tercatat angka KTP di NTB pada lima tahun terakhir mencapai 3.234 kasus, dengan rincian kasus; tahun 2008 (530 kasus), tahun 2009 (1172 kasus), tahun 2010 (1023 kasus), tahun 2011 (285 kasus), dan tahun 2012 (224 kasus). KTP didominasi atas kekerasan fisik, dengan perhitungan tidak semua kasus tercatat secara akurat dikarenakan para pelapor tidak berani atau takut melapor.

Paparan data KTP-NTB di atas, cenderung bersifat fluktuatif. Artinya data tersebut berpotensi naik turun, sehingga tidak tertutup kemungkinan terjadi peningkatan atau penurunan di tahun-tahun mendatang. Untuk itu, data tersebut masih diangggap kurang dapat dijadikan sebagai acuan nyata kekerasan gender di lapangan karena masih banyak kekerasan yang dialami perempuan yang luput dari pantauan atau liputan media massa dan masyarakat.

Pada situasi seperti ini, aksi KDRT atau non-KDRT juga kian mudah ditemukan di kolom-kolom pemberitaan media massa. Para jurnalis terkadang dianggap tidak berimbang dalam penyuguhan diksi-diksi pada teks-teks kewacanaan pemberitaan yang justru mengiris hati perempuan. Seolah-olah perempuan dianggap sulit mendapatkan tempat yang adil di tengah interaksi masyarakat. Perempuan hanya dianggap pantas berkerja dalam sektor domestik keluarga, seperti dapur, pengurus keluarga, dan rumah tangga. Selebihnya, perempuan dipandang kurang layak mengurus persoalan publik, yakni bekerja di instansi publik, wanita karier, dan segala sesuatu yang melebihi peran laki-laki. Lebih dari itu, perempuan juga kerap dianggap sebagai pemuas nafsu kaum laki-laki, sehingga tidak jarang pragmatisme masyarakat menyudutkan kaum perempuan.

Sejalan dengan itu, media sebagai 
wadah penyuguh berita yang dianggap komprehensif, sepantasnya menyajikan berita yang lebih faktual dan senantiasa berlaku cermat serta bijak dalam pemberitaannya. Pemberitaan media pada dasarnya sebagai proses rekonstruksi realitas terhadap fakta yang diperoleh para jurnalis di lapangan. Beragam realitas sosial dalam laporan pemberitaan media tidak luput dari proses kreatif para jurnalis, sehingga media dapat berpengaruh besar terhadap pola pikir masyarakat sebagai penikmat berita. Masyarakat yang diposisikan sebagai pemberi kesan terhadap berita, seyogianya bersikap kritis dan cakap dalam memaknai maksud suatu berita. Bagi masyarakat, suatu media tidak jarang dianggap kerap menyampaikan isu-isu atau realitas yang kurang berimbang. Pada akhirnya, pemberitaan yang disuguhkan, direkonstruksikan sendiri oleh para pembaca dengan penafsiran yang berbeda-beda.

Fenomena-fenomena di atas dapat dicermati melalui teks-teks pemberitaan yang diwacanakan oleh para jurnalis dalam kasus-kasus kekerasan terhadap perempuan yang dijadikan sebagai isu sensitif guna ditelaah lebih lanjut. Adanya fakta-fakta lapangan ini yang memperlihatkan isu-isu gender dalam pemberitaan media cetak Lombok Post, menciptakan peluang untuk dilakukannya pengkajian intensif terhadap teks-teks kewacanaan yang dikaji berdasarkan pendekatan Linguistik Fungisonal Sistemik (LFS) dengan mencermati permasalahan melalui sistem transitivitas dan sistem modalitas serta relevansinya terhadap pembelajaran wacana di perguruan tinggi.

Dengan demikian, pengkajian teks pemberitaan pada media cetak patut untuk ditelaah berdasarkan pendekatan LFS. Jadi, melalui penelitian yang berjudul "Kajian Linguistik Fungsional Sistemik pada Pemberitaan Kekerasan
Gender dalam Media Cetak Lombok Post dan Relevansinya Terhadap Pembelajaran Wacana di Perguruan Tinggi" diharapkan dapat dideskripsikan secara detail perihal ketidakadilan gender dalam teks media massa di NTB dan kemudian relevansinya terhadap pembelajaran wacana di perguruan tinggi.

\section{Kerangka Teori}

Pengkajian LFS diperkenalkan oleh Halliday (1994:2004). Disebut sistemic pada pengkajian ini karena berakar pada kata sistem yang artinya representasi dari teori terhadap hubungan paradigmatik. LFS yang berupaya ditelaah dengan bahasa sebagai suatu sistem tanda yang dapat dianalisis berdasarkan struktur bahasa dan penggunaan bahasa. LFS sebagai suatu kajian penelaahan dengan bahasa sebagai suatu sistem arti dan sistem lain (sistem bentuk dan ekspresi). Halliday (1994; 2004); Eggins (2004); dalam Gustianingsih (2006); dalam Adisaputra (2008) kajian LFS didasarkan pada dua konsep dasar yang berbeda dengan aliran linguistik lainnya, yakni; (a) bahasa merupakan fenomena sosial yang berwujud sebagai semiotik sosial dan (b) bahasa merupakan teks yang berkaitan dan saling memengaruhi dengan konteks sosial, sehingga kajian bahasa tidak pernah terlepas dari konteks sosial.

Gender diartikan sebagai bentuk pembeda perempuan dan laki-laki yang didasari oleh peran dan fungsi keduanya dalam masyarakat (lihat Kings, 2005:2); (Nugroho, 2008); (Darma, 2009:167) gender bukanlah pembedaan yang didasari atas jenis kelamin, tetapi lebih kepada peran dan fungsi yang lebih dominan di masyarakat. Namun demikian, perspektif gender dapat memperlihatkan peran dan kedudukan kedua belah pihak dalam teks-teks pemberitaan media. Suatu berita dianggap berimbang atau tidak, dapat 
dicermati pada struktur teks bahasa pemberitaannya yang dipergunakan, seperti yang telah ditegaskan Santoso (2009:1 - 2) bahwa perempuan dan lakilaki memiliki identitas percakapan sendiri, perempuan lebih sering dan cenderung menggunakan gaya tutur kooperatif, sebaliknya laki-laki lebih cenderung menggunakan gaya tutur kompetitif.

Analisis teks sebagai suatu studi terhadap struktur pesan dalam interaksi penutur (lisan atau tulisan) dalam komunikasi. Teks merupakan unsur utama dalam pengkajian LFS. Halliday \&Hasan, (1992:13) teks merupakan bahasa yang berfungsi, yang dimaksudkan bahasa yang sedang melaksanakan tugas tertentu dalam konteks situasi. Teks tidak terlepas dari konteks sosial, keduanya saling berhubungan erat. Karena teks merupakan tulisan yang memperkuat makna (Piliang, 2010:341). Hubungan teks dengan konteks sosial adalah hubungan konstrual, artinya konteks sosial menentukan dan ditentukan oleh teks. Dalam pada itu, Fairclough (1989); (1995:103) menjelaskan teks tidak hanya menampilkan bagaimana suatu subjek digambarkan tetapi juga bagaimana hubungan antarobjek didefinisikan. Teks merupakan unit arti atau unit semantik (makna), bukan unit tata bahasa (gramatika), seperti kata, frasa, klausa. paragraf, dan naskah. Teks terbentuk bukan dalam keadaan terisolasi, melainkan dikonstruksikan melalui sistem sosial, yaitu konteks. Halliday \& Mathiessen (2004:1) teks haruslah diperhatikan pada dua visi utama; 1) fokus pada teks sebagai objek dalam dirinya sendiri dan 2) fokus pada teks sebagai alat untuk mencari tahu tentang sesuatu yang lain. Artinya, teks dapat menyatakan dirinya melalui isi teks tersebut dan setiap teks dapat mendorong seseorang untuk memahami makna di luar teks, yaitu konteks. Namun, perlu kiranya dipertimbangkan usulan Renkema (2004:36) bahwa sesuatu hal bisa dikatakan teks tergantung situasi tertentu. Artinya, sesuatu hal bisa dikatakan teks apabila disertai dengan konteks situasi.

Konteks dalam bahasa merupakan representasi teks dalam memaknakan suatu realitas. Teks tidak bermakna apapun tanpa konteks. Eggins (2004:86) berpandangan bahwa teks tidak dapat ditafsirkan sama sekali kecuali dengan mengacu pada konteks. Teks dalam bahasa merupakan fenomena sosial yang cenderung digunakan sebagai alat berbuat sesuatu daripada mengetahui sesuatu. Hal senada pun diutarakan Gee (2011:100) bahwa konteks merupakan gagasan penting dalam memahami bahasa yang digunakan pada teks. Lebih lanjut, peran dan kedudukan perempuan dan laki-laki dapat dicermati melalui konteks teks sebagai alat untuk berbuat sesuatu hal (yakni oleh media untuk pembaca). Namun demikian, berbicara konteks dalam praktis bahasa Fairclough (2006:63 - 64; Eriyanto, 2009b:287) ada implikasi, yakni seseorang menggunakan bahasa sebagai suatu tindakan terhadap realitas dan adanya hubungan timbal balik antara wacana dan struktur sosial. Hal ini pun dapat dicermati pada media massa.

Kedudukan Media (Sobur, 2009:29); bandingkan dengan Atar (1995); penganturannya dalam UU Pers No. 40 (Tim Penyusun, 1999) sesuguhnya berada di tengah realitas sosial yang sarat dengan berbagai kepentingan, konflik, dan fakta yang kompleks dan beragam. Media berusaha sebagai perepresentasi realitas ke dalam fakta-fakta berita media. Kekuatan media tidak hanya ditentukan oleh pengaruh pada khalayak, namun juga, bagi Van Dijk (1993:241); bandingkan dengan Eriyanto (2009a;2009b) 
ditentukan oleh suatu jaringan yang kompleks, organisasi elit atau aktor sosial lainnya yang kuat. Media berpotensi untuk diintervensi oleh sekelompok pihak yang dominan atau superior. Keseluruhan fakta berita pada media bukanlah semata-mata berupa realitas di lapangan. Eriyanto (2009a:19) fakta atau peristiwa adalah hasil proses konstruksi.

Kajian LFS memiliki ciri-ciri dalam perepresentasian fungsi-fungsi bahasa yang dikenal dengan metafungsi bahasa yang terdiri atas fungsi ideasional dan fungsi interpersonal. Namun, dalam penelitian ini difoskuskan pada anlisis sistem transitivitas dan modalitas. Sistem transitivitas dijadikan oleh penutur bahasa sebagai penggambaran mental dan fakta untuk pemahaman kejadian internal dan eksternal dalam bentukbentuk proses dan modalitas sebagai penunjuk intesitas ideologi dalam realitas teks. Pengalaman pada teks media sebagai suatu bentuk proses yang sedang terjadi dalam suatu realitas ideologi golongan tertentu. Sejalan dengan itu, adanya muatan tertentu dalam teks media bagi Van Dijk (1977); (1993); (1998:138); bandingkan dengan Piliang (2010) disebut sebagai ideologi bisa diperjuangkan untuk memberdayakan kelompok-kelompok yang didominasi (tertindas), untuk membangun solidaritas, untuk mengatur perjuangan, dan mempertahankan oposisi. Lebih lanjut, bagi Saragih (2006:5), ideologi mengacu kepada konstruksi atau konsep sosial yang menetapkan apa seharusnya dan tidak seharusnya dilakukan oleh seseorang dalam satu interaksi sosial. Artinya, ideologi sebagai konsep ideal yang didambakan oleh masyarakat dalam konteks sosial tentang apa yang semestinya dilakukan dan tidak dilakukan. Pada kajian LFS atau linguitik fungsional, Schiffrin (2007:25);
Badara (2012:27) berpendapat bahwa analisis kritis ini sebagai bentuk analisis fungsional yang melihat bahasa pada fungsi sosial (peristiwa, tuturan, dan tindakan) dan sebagian besar analisis kritis dipengaruhi pandangan Halliday (2004). Hal selanjutnya, bagi Fairclough (1989:5), analisis kritis dipergunakan untuk menampilkan pandangan khusus dari yang tampak dengan yang mungkin tidak tampak dari seseorang. Dengan demikian, titik temu pandangan fungsional dengan kritis, yakni samasama mengedepankan konteks sosial sebagai pemberi makna pada teks, yakni teks pemberitaan media itu sendiri.

Lebih lanjut, upaya seseorang merealisasikan pengalaman nonlinguistik menjadi suatu pengalaman linguistik, mendorong dilakukannya pengkajian pada teks wacana. Teks sejatinya direalisasikan melalui pengalaman linguistik melalui proses transitivitas dan proses modalitas. Halliday (1994:2004); bandingkan dengan Eggins (2004); Saragih (2006) bahwa pencermatan terhadap sistem transitivitas dilakukan melalui tiga aspek, yakni proses, partisipan, dan sirkumstan dan sistem modalitas melalui empat aspek, yakni; jenis, nilai, cakupan, dan orientasi.

\section{Metode Penelitian}

Pada penelitian ini, dibedakan dua bentuk pendekatan, yakni pendekatan penelitian dan pendekatan analisis. Pendekatan penelitian merupakan suatu paradigma peneliti dalam merekonstruksi bentuk atau sifat penelitiannya, sedangkan pendekatan analisis merupakan suatu paradigma peneliti dalam merekonstruksi bentuk analisis yang dipergunakan pada suatu teks. Pendekatan penelitian yang dipergunakan berupa pendekatan kombinasi (mixed methods), yakni penggambungan dua metode penelitian, 
yakni metode penelitian kualitatif dan kuantitatif. Pendekatan ini dipergunakan bersamaan dengan asumsi dasar sebagai upaya terbaik untuk mendapatkan pemahaman terhadap permasalahan penelitian (Creswell, 2012a:535; 2012b:311); (Brannen, 2005); bandingkan dengan (Denzin \& Lincoln, 2000) dan (Syamsuddin \& Damaianti, 2009:73).

$\begin{array}{ccc}\text { Seting } & \text { penelitian } & \text { yang } \\ \text { dipergunakan pada analisis } & \text { teks }\end{array}$ pemberitaan kekerasan gender berupa penentuan lokasi, populasi, maupun sampel penelitian, tidak seperti penelitian pada umumnya. Penelitian ini menelaah data berwujud teks tulis, sebagai hasil rekonstruksi media cetak. Sumber data yang dipergunakan dengan pengumpulan langsung teks kewacanaan di media Lombok Post. Namun demikian, terkait dengan data penelitian, diperlukan beberapa sampel data yang representatif guna keterwakilan keseluruhan data, karena perlu untuk diperhatikan bahwa sampel data penelitian, cukup seseorang atau satu data tetapi representatif, sebaliknya, terlalu riskan jika data sampel hanya seseorang atau satu data saja, karena data yang diperoleh tidak bisa dikorelasikan silang demi keabsahannya. (Samarin, 1988); bandingkan dengan (Mahsun, 2007:29). Untuk itu, peneliti menetapkan pengambilan data pada harian Lombok Post yang dilakukan melalui tahapan, yakni tahap pertama dilakukan pada tanggal 1 Oktober 2012-31 Desember 2012 dan tahap kedua dilakukan pada tanggal 1 Februari 2013-31 Mei 2013 (keseluruhannya selama tujuh bulan) dengan jumlah data transkrip mencapai 46 data berita. Lebih lanjut, alasan peneliti dalam penetapan tanggal pengambilan sampel dikarenakan sirkulasi data media yang diteliti kerap menyajikan berita investigatif yang berepisode atau berkelanjutan, sehingga suatu kasus dapat diberitakan secara tuntas selama satu minggu atau bahkan sampai dengan satu bulan.

Dalam penelitian ini, metode penyediaan data yang digunakan adalah metode pustaka melalui teks-teks pemberitaan kekerasan gender pada media cetak (lihat Ratna, 2012:196). Hal ini dipergunakan guna pengumpulkan seluruh teks pemberitaan kriminal yang berperspektif gender yang menunjukkan ketidakberimbangan pembahasaan sehingga menimbulkan penafsiran di balik ideologi terselubung. Data yang terkumpul hanya bersumber pada media cetak Lombok Post dengan edisi 1 Oktober 2012-31 Desember 2012 dan edisi 1 Februari 2013-31 Mei 2013 (keseluruhannya selama tujuh bulan). Teknik yang dipergunakan dalam pengumpulan data yakni teknik baca, guna pencermatan dan pemolaan data dan teknik catat guna mendata dan melihat relasi, dalam hal ini adalah relasi setiap konstruksi diksi dalam kebahasaan media tersebut (Ratna, 2012:245; bandingkan dengan Muhammad, 2011:168); bandingkan dengan Mahsun, 2007:131). Teknik dokumentasi bertujuan untuk pengumpulan data penelitian yang bersumber pada media cetak Lombok Post (lihat Moleong, 2007:216). Di samping itu, dengan mencatat data, akan memudahkan untuk pengkategorian/pemolaan, pengolahan transitivitas, modalitas, dan pendeskripsian muatan ideologi pada teks pemberitaan.

Data dianalisis dengan metode kombinasi (mixed methods), yakni kualitatif dipergunakan untuk melakukan kategorisasi dan pemolaan diksi yang menstereotipkan perempuan atau laki-laki dalam teks media Lombok Post, sedangkan pada kuantitatif dipergunakan statistik deskriptif untuk mendeskripsikan perhitungan persentase transitivitas dan modalitas guna 
mendukung analisis kualitatif. Tujuan analisis kualitatif untuk melakukan penyeleksian dan pengorganisasian yang rasional terhadap kategori-kategori yang ada sebagai makna utama pada teks tertentu (Titscher, dkk, 2009:106); bandingkan dengan Chadwick, dkk (1991:239), sedangkan kuantitatif bertujuan untuk mendukung analisis data temuan kualitatif dalam penelitian tentang data yang terukur (misalnya; persentase transitivitas dan modalitas dalam teks pemberitaan) (Brannen, 2005:42). Dengan demikian, diperoleh gambaran yang jelas tentang bentuk dan pola serta persentase transitivitas dan modalitas yang merepresentasikan kasus KDRT dan non-KDRT dalam teks pemberitaan di media cetak Lombok Post.

Prosedur penganalisisan data kualitatif dilakukan dengan mengutip pernyataan Miles dan Huberman (1992:16); bandingkan dengan Emzir (2010) yang menyatakan bahwa tahapan penganalisisan data dapat dilakukan melalui tiga alur kegiatan yang terjadi secara bersamaan, yaitu; reduksi data, penyajian data, dan penarikan kesimpulan/verifikasi.

\section{Pembahasan}

Berdasarkan analisis sistem transitivitas dan sistem modalitas yang telah dilakukan, diperoleh data persentase kedua analisis tersebut. Adapun tabulasi analisis kedua sistem analisis dalam LFS, sebagai berikut.

\subsection{Sistem Transitivitas}

Penganalisisan sistem transitivitas dicermati berdasarkan dua kelompok kasus, yakni KDRT dan non-KDRT. Kasus KDRT terdiri atas empat subkasus yang di antaranya; perkawinan dan perceraian, pemerkosaan atau pencabulan, perebutan ahli waris, dan perselingkuhan. Lebih rinci sebagai berikut.

\subsubsection{KDRT}

Dalam kasus KDRT diperoleh 21 data kasus, dengan rincian; kasus perkawinan dan perceraian 14 data kasus, kasus perselingkuhan 4 data kasus, kasus pemerkosaan atau pencabulan 2 data kasus, dan kasus perebutan ahli waris 1 data kasus. Lebih jelasnya sebagai berikut.

Berdasarkan analisis keempat jenis kasus KDRT di atas, hasil yang diperoleh, di antaranya; kasus perkawinan dan perceraian sebanyak 14 kasus $(66,67 \%)$, kasus perselingkuhan dalam keluarga sebanyak 4 kasus $(19,04 \%)$, kasus pemerkosaan atau pencabulan dalam keluarga sebanyak 2 kasus $(9,52 \%)$, dan terakhir kasus perebutan ahli waris hanya 1 kasus $(4,76 \%)$. Telaah ini menunjukkan dominasi kasus tertinggi dalam pemberitaan KDRT diduduki atas kasus perkawinan dan perceraian dan terendah pada kasus perebutan ahli waris. Adapun deskripsinya sebagai berikut.

\subsubsection{Perkawinan atau Perceraian}

Pada kasus perkawinan atau perceraian, para jurnalis Lombok Post banyak mempergunakan proses material $(53,57 \%)$ dalam klausa teks pemberitaannya. Hal ini berarti, suatu fakta berita berusaha disuguhkan dengan proses yang dapat teramati secara empirik atau dengan panca indera. Gaya jurnalis seperti ini, sebagai usaha jurnalis dalam menyajikan pemberitaan yang nyata, kekinian, dan menjadi tren sosial dalam masyarkat NTB. Pemosisian patisipan di dalam teks pemberitaan, terdapat pada pemosisian partisipan I yang lebih dominan dibandingkan partisipan II. Hal itu artinya, motif jurnalis Lombok Post berusaha menekankan aspek partisipan I terhadap tindakan dalam suatu kasus perkawinan atau perceraian. Lebih dari itu, pemosisian perempuan pada partisipan I 
lebih sering dimunculkan dibandingkan pihak laki-laki, sebaliknya partisipan II lebih sering menjelaskan perbuatan, kesalahan, atau perilaku pihak laki-laki dibandingkan sikap perempuan dalam menuntut keadilan. Dalam hal ini, keterlibatan pihak perempuan $(52,17 \%)$ dan pihak laki-laki $(47,83 \%)$, dengan catatan bahwa dalam setiap kasusnya pihak perempuan lebih mendominasi sebagai korban $(70 \%)$ dan sebagai pelaku $(38,46 \%)$, sedangkan pihak lakilaki mendominasi sebagai pelaku $(61,54 \%)$ dan sebagai korban $(38,46 \%)$.

Untuk itu, dapat interpretasikan bahwa motif jurnalis berusaha mengontraskan korban perempuan seoalah-olah sebagai pelaku dan pelaku laki-laki seolah-olah sebagai korban. Pada penulisan sirkumstan, para jurnalis kerap menyajikan lingkup keterangan cara atau sirkumstan cara $(43,43 \%)$ dalam setiap teks pemberitaan kasus perkawinan atau perceraian, artinya suatu jurnalis berusaha mengabstraksikan dan mendeksripsikan serta menonjolkan beragam pola tingkah para pelaku (perempuan atau laki-laki) dan korban (perempuan atau laki-laki) ditampilkan dalam teks pemberitaan. Hal ini dapat dicermati pada cuplikan teks berikut.

\section{Data 1 [inti berita]}

\begin{tabular}{|l|l|l|l|l|l|l|l|}
\hline $\begin{array}{l}\text { Santriwati } \\
\text { itu }\end{array}$ & bukan & istri & tapi & teman & hidup & bagi & Ulrich \\
\hline nomina & keterangan & nomina & penghubung & nomina & verba & penghubung & nomina \\
\hline subjek & Adverbial & & & $\begin{array}{l}\text { predikator } \\
\text { adoses: } \\
\text { tingkah } \\
\text { laku }\end{array}$ & resipen & \\
\hline $\begin{array}{l}\text { Petingkah } \\
\text { laku }\end{array}$ & $\begin{array}{l}\text { Sirkumstan: } \\
\text { cara }\end{array}$ & & & & & \\
\hline
\end{tabular}

\subsubsection{Perselingkuhan}

Serupa dengan kasus di atas, juga dalam kasus perselingkuhan dalam keluarga, didominasi juga atas proses material $(47,62 \%)$. Proses ini menujukkan bahwa motif para jurnalis Lombok Post yang berusaha mengungkap abstraksi nyata suatu kasus dalam sebuah pemberitaan. Lanjut lagi, penggunaan partisipan I yang lebih dominan daripada partisipan II bertanda penulis berita sangat menekankan siapa pelaku, dibandingkan sasaran pelaku itu sendiri.

Hal tersebut dapat dicermati pada beberapa kasus perselingkuhan yang kerap dilakukan oleh pihak perempuan terhadap lelaki lain, tetapi jurnalis tidak berusaha mengungkap penyebab istri kenapa melakukan perselingkuhan.
Untuk itu, perlu dicermati tingkat keterlibatan pihak perempuan dalam kasus ini $(55,56 \% \%)$ dengan rincian sebagai pelaku $(66,67 \%)$ dan sebagai korban $(33,33 \%)$, sedangkan pihak lakilaki $(44,44 \%)$ dengan rincian sebagai pelaku $(33,33 \%)$ dan sebagai korban $(66,67 \%)$. Ini artinya bahwa pemerkosaan hanya terjadi terhadap perempuan yang disebabkan oleh pihak laki-laki. Lebih dari itu, pada tataran pemunculan sirkumstan dalam teks pemberitaan, sirkumstan cara paling mendominasi dengan (55,55\%). Ini artinya seorang wartawan berusaha mendeksripsikan lingkup tindakan yang dilakukan para pelaku, dalam hal ini perselingkuhan yang dilakukan istri dengan laki-laki lain, seperti halnya pada cuplikan kasus berikut. 


\section{Data 24 [awal berita]}

\begin{tabular}{|l|l|l|l|l|l|l|l|l|}
\hline Tindakan & asusila & tersebut & dilakukan & $\begin{array}{l}\text { ADA } \\
\text { [si } \\
\text { Hakim } \\
\text { Cantik }]\end{array}$ & Saat & ADA & Bertugas & $\begin{array}{l}\text { di } \\
\text { Tengah }\end{array}$ \\
\hline nomina & adjektif & verba & verba & nomina & Nomina & nomina & Verba & keterangan \\
\hline objek & adverbia & predikator & subjek & Subjek & Predicator & adverbia \\
\hline gol & Sirkumstan: masalah & proses & pelaku & Petingkah laku & Proses & $\begin{array}{l}\text { Sirkumstan: } \\
\text { lokasi: } \\
\text { tempat }\end{array}$ \\
\hline
\end{tabular}

\subsubsection{Pemerkosaan atau Pencabulan}

Dalam kasus pemerkosaan atau pencabulan dalam keluarga, persentase proses material paling mendominasi $(31,82 \%)$. Hal ini bertanda bahwa seorang wartawan berupaya menyajikan suatu kasus secara nyata dan seolah-olah pembaca dapat melihat, mengabstraksikan kasus, dan terjadi di hadapannya, sedangkan itu pada aspek pihak yang terlibat dalam teks pemberitaan, yakni partisipan I yang kerap menampilkan pihak laki-laki lebih dominan dibandingkan partisipan II yang terkadang menampilkan pihak perempuan. Dalam pada itu, tindakan pemerkosaan atau pencabulan hanya dilakukan oleh pihak laki-laki (100\%) terhadap perempuan, sehingga korban selalu dialami kaum perempuan (100\%).

Namun demikian, perlu dicermati, konstruksi teks pemberitaan pada kasus ini kerap dipergunakan penyataan yang berupa angapan-anggapan atau menduga-duga, padahal pelaku sudah ditetapkan bersalah. Sejalan dengan itu, penggunaan sirkumstan dalam setiap klausanya didominasi atas sirkumstan cara $(55,56 \%)$ yang bertanda, seorang wartawan berusaha mendeskripsikan perilaku para pelaku dalam melakukan pemerkosaan atau pencabulan. Hal ini dapat dicermati pada cuplikan kasus sebagai berikut.

Data 5 [inti berita]

\begin{tabular}{|l|l|l|l|l|l|l|l|l|l|}
\hline Korban & kaget & karena & mendapati & $\begin{array}{l}\text { sang } \\
\text { ayah }\end{array}$ & Berada & di atas & tubuhnya & Dia & berteriak \\
\hline nomina & $\begin{array}{l}\text { Adjek- } \\
\text { tiva }\end{array}$ & $\begin{array}{l}\text { Penghu- } \\
\text { bung }\end{array}$ & verba & nomina & Verba & $\begin{array}{l}\text { Kete- } \\
\text { rangan }\end{array}$ & nomina & $\begin{array}{l}\text { Nomin } \\
\text { a }\end{array}$ & Verba \\
\hline Adverbial & & & subjek & predikator \\
\hline \multicolumn{2}{|l|}{ Sirkumstan: cara } & \multicolumn{2}{l}{ Sirkumstan: sebab } & $\begin{array}{l}\text { Pembic } \\
\text { ara }\end{array}$ & $\begin{array}{l}\text { Proses: } \\
\text { verbal }\end{array}$ \\
\hline
\end{tabular}

\subsubsection{Perebutan Ahli Waris}

Kasus terakhir, teks pemberitaan KDRT yang terkait dengan kasus perebutan ahli waris, penggunaan proses material paling mendominasi dalam setiap klausa pada kasus ini sebesar $(31,25 \%)$. Hal ini menandakan para wartawan berusaha menunjukkan tindakan yang seoalah-olah direalisasikan nyata, teramati, dan dapat diabstraksikan dalam pemikiran masyarakat. Pada aspek berikutnya, penggunaan partisipan I (sebagian besar pelaku perempuan) lebih dominan dibandingkan dengan partisipan II (sebagaian besar sasaran aksi pihak lakilaki), artinya bahwa pihak perempuan kerap tampil sebagai penuntut (100\%) pihak laki-laki dalam persoalan pasca perceraian atau perempuan yang dipoligami, sedangkan pihak laki-laki sebagai partisipan yang dituntut (100\%). 
Pada sirkumstan yang ditemukan sebagian besar berupa sirkumstan cara yang menunjukkan sikap dan tindakan para partisipan dalam teks pemberitaan suatu kasus. Contoh data dapat dicermati pada cuplikan kasus berikut.

Data 2 [awal berita]

\begin{tabular}{|l|l|l|l|l|l|l|l|}
\hline Satriawati & ingin & menguasai & aset & mendiang & berupa & $\begin{array}{l}\text { tiga } \\
\text { mobil }\end{array}$ & $\begin{array}{l}\text { Toyota Alpahard, } \\
\text { Toyota Fortuner, } \\
\text { dan KIA Karnival }\end{array}$ \\
\hline nomina & keterangan & verba & nomina & nomina & verba & $\begin{array}{l}\text { keterang } \\
\text { an }\end{array}$ & Nomina \\
\hline subjek & adverbia & predikator & Objek & Adverbial \\
\hline pelaku & $\begin{array}{l}\text { sirkumstan: } \\
\text { cara }\end{array}$ & $\begin{array}{l}\text { proses: } \\
\text { material }\end{array}$ & Gol & \multicolumn{2}{|l|}{ sirkumstan: masalah } \\
\hline
\end{tabular}

\subsubsection{Non-KDRT}

Berdasarkan analisis terhadap kelima jenis kasus non-KDRT di atas, diperoleh data temuan sebanyak 25 kasus dengan rincian; pemerkosaaan atau pencabulan 18 kasus, pembunuhan 3 kasus, gratifikasi seks atau pencabulan 2 kasus, pemukulan atau penganiayaan 1 kasus, dan perampasan atau perampokkan 1 kasus. Sehingga demikian, persentase kasus non-KDRT $54,35 \%$, lebih tinggi dibandingkan data temuan pada kasus KDRT dengan persentase $45,65 \%$ (total 21 kasus). Dalam pada itu, pada proses pencermatan setiap kasus temuan, didapat persentase kasus dalam nonKDRT, didominasi atas kasus pemerkosaan atau pencabulan, sedangkan kasus pemukulan atau penganiayaan dan perampasan atau perampokan sebagai kasus non-KDRT terendah. Lebih jelasnya, dapat dicermati pada deskripsi di bawah ini.

\subsubsection{Pemerkosaan atau Pencabulan}

Pada kasus pemerkosaan atau pencabulan, ditemukan konstuksi klausa para jurnalis dalam teks pemeberitaan non-KDRT di Lombok Post yang didominasi atas proses material $(43,79 \%)$. Hal ini berarti, seorang wartawan dalam peliputan dan pelaporan

Data 23 [awal berita] suatu kasus, berusaha mendeskripsikan pemberitaan secara faktual dengan penyajian pola atau tingkah para pelibat dalam suatu teks pemberitaan. Pada aspek pelibat dalam teks, terdapat pemosisian partisipan I $(55,82 \%)$ lebih dominan dibandingkan partisipan II $(44,18 \%)$ yang berarti para wartawan dalam perekonstruksian suatu kasus, sangat ditekankan pada partisipan I sebagai pelaku aksi atau tindakan dalam suatu kasus.

Dalam pada itu, keterlibatan para partisipan yang terdiri atas pihak perempuan dan pihak laki-laki dengan rincian persentase, yakni tingkat keterlibatan pihak perempuan $(50 \%)$ dengan peranan hanya sebagai korban (100\%), sebaliknya pihak laki-laki dengan tingkat keterlibatan $(50 \%)$ tetapi hanya berperan sebagai pelaku (100\%). Itu artinya, pihak perempuan kerap sebagai korban penderita atas tindakan yang dilakukan pihak laki-laki. Di samping itu, juga terdapat penggunaan sirkumstan lokasi (tempat dan waktu) $47,33 \%$, yang berarti suatu teks pemberitaan lebih ditonjolkan pada pengidentifikasian lokasi kasus guna perekonstruan relaitas dalam pemberitaan. Contoh data dapat dicermati pada analisis kasus berikut.

\begin{tabular}{|l|l|l|l|l|l|l|l|}
\hline Pelecehan & seksual & kembali & terjadi & Pada & anak & usia & Dini \\
\hline nomina & nomina & verba & verba & Penghubung & nomina & nomina & Adjektiva \\
\hline subjek & predikator & Adverbial \\
\hline maujud & proses: wujud & Resipen \\
\hline
\end{tabular}




\subsubsection{Pembunuhan}

Pada kasus pembunuhan, diperoleh dominasi proses material $(61,54 \%)$, partisipan I $(54,54 \%)$ dan pelibat pihak perempuan $(60 \%)$ dengan rincian hanya sebagai korban $100 \%$ dan pelaku $(33,33 \%)$, sedangkan pihak laki-laki (40\%) dengan rincian sebagai pelaku $(66,67 \%)$ dan tidak pernah menjadi korban pembunuhan oleh perempuan, dan sirkumstan masalah $(14,29 \%)$.
Keseluruhan persentase pada kasus pembunuhan ini diperlihatkan sikap wartawan dalam menyajikan kasus pembunuhan dengan pengabtraksian realitas secara faktual melalui pengidentifikasian tingkat keterlibatan partisipan perempuan dan laki-laki dalam berbagai motif masalah yang memicu timbulnya suatu konflik gender. Contoh data dapat dicermati pada analisis berikut.

\section{Data 4 [awal berita]}

\begin{tabular}{|l|l|l|l|l|l|l|}
\hline $\begin{array}{l}\text { Azwar } \\
\text { Hamid }\end{array}$ & Yang & Tega & menghabisi & Nyawa & pacarnya & Sendiri \\
\hline Nomina & penghubung & Adjektif & verba & Nomina & nomina & Keerangan \\
\hline Subjek & $\begin{array}{l}\text { adverbia } \\
\text { Pelaku }\end{array}$ & $\begin{array}{l}\text { Serba } \\
\text { Sirkumstan: }\end{array}$ & $\begin{array}{l}\text { Proses: } \\
\text { cara }\end{array}$ & nomina & Nomina & \\
\hline
\end{tabular}

\subsubsection{Pemukulan atau Penganiayaan}

Dalam kasus pemukulan atau penganiayaan, didominasi atas beberapa aspek, yakni proses material $(37,5 \%)$, partisipan I $(53,33 \%)$ dan keterlibatan partisipan perempuan (50\%) dengan hanya sebagai korban pihak laki-laki $(100 \%)$, sedangkan keterlibatan pihak laki-laki $(50 \%)$ dengan hanya sebagai pelaku pemukulan atau penganiayaan terhadap perempuan (100\%), dan sirkumstan lokasi (83,33\%). Hal ini Data 12 [awal berita]

\begin{tabular}{|c|c|c|c|c|c|}
\hline Seorang & wanita & yang & Tinggal & $\begin{array}{l}\text { di sebuah cafe } \\
\text { kawasan Batu Gong }\end{array}$ & babak belur \\
\hline Nomina & Nomina & penghubung & Verba & keterangan & Keterangan \\
\hline subjek & Predikator & adverbia & \multicolumn{3}{|c|}{ Adverbial } \\
\hline $\begin{array}{l}\text { Petingkah } \\
\text { laku }\end{array}$ & Proses:tingkah laku & $\begin{array}{l}\text { Sirkumstan: } \\
\text { lokasi: tempat }\end{array}$ & \multicolumn{3}{|c|}{ Sirkumstan: cara } \\
\hline
\end{tabular}

\subsubsection{Gratifikasi Seks atau Prostitusi}

Pada kasus gratifikasi seks atau prostitusi diperoleh dominasi proses verbal $(42,85 \%)$, partisipan I $(61,76 \%)$ dan keterlibatan pihak perempuan $(50 \%)$ dengan hanya sebagai korban (100\%), sebaliknya keterlibatan pihak laki-laki (50\%) dengan hanya sebagai pelaku $(100 \%)$, dan sirkumstan cara (40\%). Hal sebagai penanda bahwa sikap jurnalis dalam pemberitaan kasus pemukulan atau penganiayaan, diidentifikasi secara faktual dengan dikedepankannya aspek yang teramati (nyata) dalam berbagai konteks lokasi (waktu dan tempat) dengan pedeskripsian intensitas keterlibatan pelaku laki-laki sebagai pelaku yang melakukan pemukulan atau penganiayaan terhadap korban perempuan. Contoh data dapat dicermati pada analisis berikut.

ini berarti pihak wartawan dalam pemberitaan berusaha menyajikan kasus gratifikasi seks atau prostitusi dengan penekanan pada aspek pengakuan para pelaku atau pelibat kasus, yakni antara pihak perempuan dan laki-laki yang ditampilkan dalam berbagai motif atau cara tindakan. Contoh data dapat dicermati pada cuplikan analisis berikut. 
Data 20 [awal berita]

\begin{tabular}{|c|c|c|c|c|c|c|c|c|c|}
\hline $\begin{array}{l}\text { Maha- } \\
\text { siswi }\end{array}$ & sebuah & $\begin{array}{l}\text { universi- } \\
\text { tas swasta }\end{array}$ & $\begin{array}{l}\text { di } \\
\text { Jakarta } \\
\text { itu }\end{array}$ & $\begin{array}{l}\text { keda- } \\
\text { patan }\end{array}$ & $\begin{array}{l}\text { ber- } \\
\text { duaan }\end{array}$ & dengan & $\begin{array}{l}\text { Ahmad } \\
\text { Fathanah }\end{array}$ & $\begin{array}{l}\text { orang } \\
\text { dekat } \\
\text { Lutfi } \\
\text { Hasan } \\
\text { Ishaq }\end{array}$ & $\begin{array}{l}\text { di kamar } \\
\text { Hotel Le } \\
\text { Meridien }\end{array}$ \\
\hline Nomina & Nomina & nomina & $\begin{array}{l}\text { kete- } \\
\text { rangan }\end{array}$ & verba & Verba & $\begin{array}{l}\text { Peng- } \\
\text { hubung }\end{array}$ & nomina & $\begin{array}{l}\text { ketera } \\
\text { ngan }\end{array}$ & keterangan \\
\hline Subjek & predikator & \multicolumn{8}{|l|}{ Adverbial } \\
\hline $\begin{array}{l}\text { Peting- } \\
\text { kah laku }\end{array}$ & $\begin{array}{l}\text { Proses: } \\
\text { tingkah } \\
\text { laku }\end{array}$ & $\begin{array}{l}\text { Sirkumsta: } \\
\text { penyerta }\end{array}$ & \multicolumn{7}{|c|}{ sirkumstan: lokasi: tempat } \\
\hline
\end{tabular}

\subsubsection{Perampasan atau Perampokan}

Pada pemberiataan kasus yang terakhir tentang tidak perampasan atau perampokan yang dialami para partisipan yang didominasi atas proses material (60\%), partisipan I $(62,5 \%)$ dan keterlibatan pihak perempuan (50\%) dengan hanya sebagai korban $(100 \%)$ kekerasan pihak laki-laki, sedangkan keterlibatan pihak laki-laki (50\%) dengan hanya sebagai pelaku $(100 \%)$ kekerasan terhadap perempuan, dan sirkumstan lokasi (40\%). Persentase ini menandakan bahwa sikap wartawan dalam pemberitaan kasus perampasan atau perampokan yang disajikan secara faktual dengan pendeskripsian keterlibatan para partisipan dan pendeskripsian kasus dengan mencermati setiap lokasi kejadinya. Contoh data analisis dapat dicermati pada cuplikan kasus berikut.

Data 21 [awal berita]

\begin{tabular}{|c|c|c|c|c|c|c|c|c|c|c|c|}
\hline $\begin{array}{l}\text { Pen- } \\
\text { jamb- } \\
\text { retan }\end{array}$ & $\begin{array}{l}\text { Kem- } \\
\text { bali }\end{array}$ & terjadi & $\begin{array}{l}\text { di wila- } \\
\text { yah } \\
\text { hukum } \\
\text { Polres } \\
\text { Mata- } \\
\text { ram }\end{array}$ & kali & ini & $\begin{array}{l}\text { korban- } \\
\text { nya }\end{array}$ & $\begin{array}{l}\text { seoran } \\
\mathrm{g}\end{array}$ & guru & privat & $\begin{array}{l}\text { Ni Putu } \\
\text { Lia } \\
\text { Triadan, } \\
23 \\
\text { tahun }\end{array}$ & $\begin{array}{l}\text { warga } \\
\text { Baba- } \\
\text { kan, } \\
\text { Kelu- } \\
\text { rahan } \\
\text { Turida. }\end{array}$ \\
\hline $\begin{array}{l}\text { Nomi- } \\
\text { na }\end{array}$ & Verba & Verba & $\begin{array}{l}\text { Kete- } \\
\text { rangan }\end{array}$ & $\begin{array}{l}\text { nomi- } \\
\text { na }\end{array}$ & pron. & Nomina & nomina & $\begin{array}{l}\text { nomi- } \\
\text { na }\end{array}$ & $\begin{array}{l}\text { adjek- } \\
\text { tifa }\end{array}$ & nomina & $\begin{array}{l}\text { Kete- } \\
\text { rangan }\end{array}$ \\
\hline subjek & $\begin{array}{l}\text { Predi- } \\
\text { kator }\end{array}$ & $\begin{array}{l}\text { predika- } \\
\text { tor }\end{array}$ & \multicolumn{9}{|l|}{ Adverbia } \\
\hline $\begin{array}{l}\text { mau- } \\
\text { jud }\end{array}$ & $\begin{array}{l}\text { Pro- } \\
\text { ses: } \\
\text { wujud }\end{array}$ & $\begin{array}{l}\text { Sirkum- } \\
\text { stan: } \\
\text { lokasi: } \\
\text { tempat }\end{array}$ & $\begin{array}{l}\text { Sirkum- } \\
\text { stan: } \\
\text { masalah }\end{array}$ & \multicolumn{8}{|c|}{ Sirkumstan: lokasi: tempat } \\
\hline
\end{tabular}

Terkait dengan analisis transitivitas terhadap beberapa kasus di atas, diperoleh fakta bahwa kasus kekerasan terhadap perempuan atau laki-laki didominasi atas kekerasan fisik. Hal ini dibuktikan dengan pemberitaan faktual yang mengedepankan proses material (terkait fisik dan teramati), partisipan dan pelibat wacana yang memosisikan perempuan sebagai korban dan laki-laki sebagai pelaku, dan sirkumstan cara dan lokasi yang menunjukkan lingkup pengidentifikasian realitas dalam sebuah fakta berita. Sehingga demikian, kasus kekerasan gender (KDRT dan NonKDRT) di NTB, sebagian besar korban ditimbulkan akibat kekerasan fisik, di antaranya: pemukulan, pelecehan 
seksual, dan bahkan pembunuhan.

\subsection{Sistem Modalitas}

Pencermatan modalitas terhadap teks pemberitaan kekerasan gender dalam media cetak Lombok Post dilakukan dengan dua aspek, yakni representasi tindakan perempuan terhadap laki-laki dan representasi tindakan laki-laki terhadap perempuan. Adapun penjelasannya secara rinci sebagai berikut.

\subsubsection{Representasi Tindakan Perempun}

Tindakan yang pelaku utamanya pihak perempuan, pada teks pemberitaan kekerasan gender di media cetak Lombok Post, pada dasarnya dilakukan sebagai upaya pertahan diri perempuan terhadap sikap dan perilaku pihak lakilaki dalam interaksi di masyarakat. Kedudukan perempuan yang kerap dianggap inferior dan lemah dihapadan pihak laki-laki, tak luput dianggap berakibat pada tingginya kasus kekerasan gender di masyarakat.

Dalam pada itu, diperlukan penganalisisan atau pencermatan terhadap tindakan atau perilaku pihak perempuan terhadap laki-laki melalui sistem modalitas yang menelaah aspek probabilitas (kemungkinan), keseringan, keharusan, dan kecenderungan sikap atau tindakan pelaku dalam teks pemberitaan. Untuk itu, penganalisisan terhadap data teks didapat atau ditemukan pada pemberitaan kekerasan gender dengan pelaku utamanya, yakni pihak perempuan, diperoleh sebanyak 9 data $(19,57 \%)$ dengan kelompok data temuan termasuk dalam probabilitas dan kecenderungan. Adapun, data temuan diperoleh pada; data 1 , data 2 , data 3 , data 19 , data 20 , data 22 , data 24 , data 27 , dan data 40 yang deskripsinya dapat dicermati pada tabel 4.0, di bawah ini.

\begin{tabular}{|c|c|c|c|c|c|}
\hline \multicolumn{6}{|c|}{ Tindak Perilaku Perempuan terhadap Laki-Laki } \\
\hline \multicolumn{6}{|c|}{ Polar Positif } \\
\hline Modalisasi & & & Modulasi & & \\
\hline Probabilitas & Jumlah & $(\%)$ & Kecenderungan & Jumlah & $(\%)$ \\
\hline 'pasti' & 38 & 79,17 & 'ditetapkan' & - & - \\
\hline 'mungkin' & 10 & 20,83 & 'mau' & 3 & 60 \\
\hline 'barangkali' & - & - & 'ingin’ & 2 & 40 \\
\hline TOTAL & 48 & 100 & TOTAL & 5 & 100 \\
\hline \multicolumn{6}{|c|}{ Polar Negatif } \\
\hline Kasus pada & & & Jumlah & & \\
\hline Pihak Perempuan & & & 9 & & \\
\hline
\end{tabular}

Tabel 4.0: Persentase Modalitas dalam Tindakan Perempuan terhadap Laki-laki

Berdasarkan tabel 4.0 tantang presentasi modalitas dalam tindakan perempuan terhadap laki-laki di atas, diperoleh persentase modalisasi dengan probabilitas tinggi (pasti) sebesar $79,17 \%$ dan probabilitas menengah sebesar $20,83 \%$, sedangkan probabilitas rendah tidak ditemukan. Hal ini artinya tindakan kekerasan gender di NTB yang pelakunya, dilakukan pihak perempuan terhadap laki-laki memiliki tingkat kepastian yang tinggi (nyata), di samping terdapat tindakan perempuan yang bersifat kemungkinan. Dalam pada itu, juga terdapat persentase modulasi dengan tingkat kecenderungan mendengah sebesar $60 \%$ dan kecenderungan rendah sebesar 40\%, sehingga dapat dipastikan tindakan pihak perempuan terhadap laki-laki dalam teks pemberitaan kekerasan gender pada media Lombok Post bersifat mau atau akan, yang artinya tindakan tersebut masih dalam tahap perencanaan belum sampai pada tahap pengaktualisasian.

\subsubsection{Representasi Tindakan Laki- laki}

Pada representasi tindakan yang 
pelaku utamanya pihak laki-laki dalam teks pemberitaan kekerasan gender di media cetak Lombok Post diperlihatkan pada korban kekerasan gender yang banyak dialami pihak perempuan. Sejalan dengan itu, data temuan yang terkait dengan tindakan pihak laki-laki terhadap pihak perempuan atau dalam hal ini pihak laki-laki sebagai pelaku utama dalam teks pemberitaan, diperoleh data teks pemberitaan kekerasan gender sebanyak 37 data $(80,43 \%)$, artinya tindakan kekerasan gender yang dilakukan pihak laki-laki terhadap perempuan lebih dominan, jika dibandingkan tindak kekerasan gender yang dilakukan pihak perempuan terhadap pihak laki-laki yang hanya berjumlah 9 data.

Dalam pada itu, data temuan yang didapat pada teks pemberitaan kekerasan gender di media cetak Lombok Post di antaranya pada; data 4 , data 5 , data 6 , data 7 , data 8 , data 9 , data 10 , data 11 , data 12 , data 13 , data 14 , data 15 , data 16 , data 17 , data 18 , data 21 , data 23 , data 25 , data 26 , data 28 , data 29 , data 30 , data 31 , data 32 , data 33 , data 34 , data 35 , data 36 , data 37 , data 38 , data 39 , data 41 , data 42 , data 43 , data 44 , data 45, dan data 46. Adapun persentase modalitas data temuan yang diperoleh terkait dengan tindakan pihak laki-laki terhadap perempuan dapat dicermati pada tabel 4.1, di bawah ini.

\begin{tabular}{|c|c|c|c|c|c|}
\hline \multicolumn{6}{|c|}{ Tindak Perilaku Laki-laki terhadap Perempuan } \\
\hline \multicolumn{6}{|c|}{ Polar Positif } \\
\hline \multicolumn{6}{|c|}{ Modalisasi } \\
\hline Probabilitas & Jumlah & $(\%)$ & Keseringan & Jumlah & $(\%)$ \\
\hline 'pasti' & 137 & 79,19 & 'selalu’' & 9 & 100 \\
\hline 'mungkin' & 36 & 20,81 & 'biasa' & - & - \\
\hline 'barangkali' & - & - & 'kadang-kadang’ & - & - \\
\hline TOTAL & 173 & 100 & TOTAL & 9 & 100 \\
\hline \multicolumn{6}{|c|}{ Modulasi } \\
\hline Keharusan & Jumlah & $(\%)$ & Kecenderungan & Jumlah & $(\%)$ \\
\hline ‘wajib’ & 5 & 45,45 & 'ditetapkan' & 4 & 22,22 \\
\hline 'diharapkan' & 6 & 54,54 & 'mau' & 12 & 66,67 \\
\hline 'boleh' & - & - & ‘ingin’ & 2 & 11,11 \\
\hline TOTAL & 11 & 100 & TOTAL & 18 & 100 \\
\hline \multicolumn{6}{|c|}{ Polar Negatif } \\
\hline Kasus pada & & & Jumlah & & \\
\hline Pihak Laki-laki & & & 22 & & \\
\hline
\end{tabular}

Tabel 4.1: Persentase Modalitas dalam Tindakan Laki-laki terhadap Perempuan

Berdasarkan tabel 4.1 tentang persentase modalitas dalam tindakan laki-laki terhadap perempuan di atas, diperoleh beberapa persentase, di antaranya 1) persentase modalisasi (dengan probabilitas tinggi (pasti) 79,19\%, probabilitas menengah (mungkin) 20,81\%, dan keseringan tinggi (selalu) 100\%) dan 2) persentase modulasi (dengan persentase keharusan tinggi (wajib) 45,45\%, persentase keharusan menengah (diharapkan) $54,54 \%$ dan persentase kecenderungan tinggi (ditetapkan) 22,22\%, persentase menengah $(66,67 \%)$, dan persentase rendah (ingin) 11,11\%).

Keseluruhan persentase modalitas dalam teks berita kekerasan gender pada media Lombok Post di atas, dapat dicermati bahwa tindak kekerasan gender di NTB, sebagian besar 
dilakukan atau pelaku utamanya adalah pihak laki-laki (dibuktikan dengan persentase pada tingkat probabilitas tinggi) dan perempuan kerap dijadikan sebagai korban atau penderita dalam setiap peristiwa. Di samping itu, tindakan kekerasan gender yang dilakukan laki-laki di NTB sudah teraktualisasikan atau dilakukan dan menimbulkan korban kekerasan gender, sebaliknya pihak perempuan probabilitas tindakan "pasti" lebih rendah dibandingkan pihak laki-laki, sehingga perempuan di NTB kerap menjadi sasaran kekerasan kaum lak-laki.

\subsection{Relevansi Kajian terhadap Pembelajaran Wacana di Perguruan Tinggi}

Terkait dengan pengkajian dalam penelitian ini, peneliti membagi kerelevansian penelitian terhadap pembelajaran mata kuliah wacana di perguruan tinggi melalui dua aspek, yakni pada aspek keurgensian kajian dan aspek kebermanfaatan kajian. Adapun deskripsinya sebagai berikut.

\subsubsection{Keurgensian Kajian}

Pada aspek keurgensian kajian, hal yang direlevansikan berupa hasil pengkajian peneliti berupa nilai-nilai sosial, seperti; nilai moral (asusila), nilai keadilan, dan nilai tanggung jawab yang diperoleh dalam wacana teks pemberitaan kekerasan gender dalam media cetak Lombok Post. Kasus yang didapat peneliti dalam teks pemberitaan kekerasan gender dalam media cetak Lombok Post di antaranya memuat kasus KDRT yang meliputi; perkawinan dan perceraian, pemerkosaan dan pencabulan, perebutan ahli waris, dan perselingkuhan, sedangkan kasus NonKDRT terdiri atas kasus; pemerkosaan atau pencabulan, pembunuhan bermotifkan asmara, pemukulan atau penganiayaan, gratifikasi seks (sex), dan perampasan atau perampokan. Dengan demikian, cukup relevan penerapan hasil pengkajian peneliti terhadap fenomena atau gejala sosial yang saat ini marak terjadi di masyarakat. Di samping itu, pengintegrasian materi kekerasan gender dalam pembelajaran di perguruan tinggi dapat dijadikan sebagai langkah preventif untuk meminimalisir kasus gender pelecehan seksual, kekerasan seksual, bahkan pembunuhan.

\subsubsection{Kebermanfaatan Kajian}

Pada aspek kebermanfaatan kajian, hal yang direlevansikan berupa teknik atau cara pengkajian LFS dalam penganalisisan suatu teks kewacanaan pada pembelajaran. Teks dapat beragam wujud, tetapi dalam hal ini teks berupa pemberitaan kekerasan gender. Lebih dari itu, kajian LFS pada mata kuliah kewacanaan di perguruan tinggi memiliki jangkauan kajian yang komprehensif jika dibandingkan dengan kajian kewacaan yang lainnya. Artinya, segala fenomena atau gejala sosial yang bermakna dan direkontruksikan oleh konteks maka itu dikatakan sebagai teks, dan teks inilah yang dijadikan sebagai domain kajian dalam LFS sehingga hasil pengkajian cukup detail, lengkap, dan akurat.

\section{Penutup}

Berdasarkan pembahasan di atas, dapat disimpulkan bahwa konstruksi teks berita kekerasan gender pada media Lombok Post sebagian besar memosisikan laki-laki lebih sering sebagai pelaku kekerasan gender, dibandingkan dengan perempuan yang kerap diposisikan sebagai korban (meskipun pihak perempuan terkadang juga diposisikan sebagai pelaku tindakan) dalam beberapa kasus kekerasan gender. Untuk lebih jelasnya dalam penelitian ini menghasilkan 
temuan kemudian menjadi kesimpulan analisis.

Analisis transitivitas pada kasus KDRT pada teks media di NTB, sebagian besar teks ditampilkan dalam proses material dengan sirkumstan cara, sedangkan pada pelibat, yakni pihak laki-laki mendominasi pada kasus perkawinan atau perceraian, kasus pemerkosaaan atau pencabulan, sedangkan pihak perempuan mendominasi pada kasus perebuatan ahli waris dan perselingkuhan. Sebaliknya, pada kasus perkawinan atau perceraian dan pemerkosaan perempuan lebih dirugikan karena hanya sebagai korban, sedangkan pada kasus perebutan ahli waris dan perselingkuhan justru pihak laki-laki dirugikan karena kerap sebagai korban aksi oleh perempuan.

Analisis transitivitas pada kasus Non-KDRT pada teks media di NTB, sebagian besar teks ditampilkan pada proses material dengan sirkumstan lokasi dan cara, sedangkan pelibat pihak lakilaki sangat mendominasi peran pelaku pada seluruh jenis kasus non-KDRT. Hal ini artinya, dalam setiap kasus, pihak perempuan kerap dijadikan sebagai korban, seperti dalam kasus; pemerkosaan atau pencabulan, pembunuhan, pemukulan atau penganiayaan, gratifikasi seks (sex) atau prostitusi dan perampasan atau perampokan.

Analisis sistem modalitas pada tindakan pihak laki-laki terhadap perempuan lebih dominan dibandingkan tindakan perempuan terhadap laki-laki. Dalam intensitas dan jenis tindakan pihak laki-laki kerap bertindak dalam tingkat kepastian (tinggi) sehingga tindakannya sudah terealisasi, sedangkan perempuan hanya sebagian kecil saja yang terealisasi dan di antaranya masih dalam tahap keinginan dan perencanaan tindakan.

Dengan demikian, pada kasus kekerasan gender dalam pemberitaan media cetak di NTB, pihak laki-laki diposisikan sebagai pelaku tindakan fisik dan psikis, sedangkan pihak perempuan sebagai korban kekerasan pihak lakilaki. Realitas persoalan ini selayaknya harus segera menjadi prioritas dalam pemberdayaan kehidupan sosial di masyarakat NTB. Pemerintah harus tanggap dan bertindak cepat dalam mencegah terjadinya kasus kekerasan gender di masyarakat. Salah satunya, dapat dilakukan melalui pembelajaran di perguruan tinggi, sehingga pada akhirnya tingkat KDRT dan Non-KDRT dapat diminimalisir atau bahkan dicegah.

\section{Daftar Pustaka}

Adisaputra, Abdurahman. 2008. Linguistik Fungsional Sistemik: Analisis Teks Materi Pembelajaran di Sekolah Dasar $(S D)$. Jurnal Ilmiah Bahasa dan Sastra (LOGAT) Vol. IV, No. 1: $12-21$.

Atar, Semi. 1995. Teknik Penulisan Berita, Features, dan Artikel. Bandung: Angkasa.

Badara, Aris. 2012. Analisis Wacana: Teori, Metode, dan Penerapannya pada Wacana Media. Jakarta: Kencana.

Brannen, Julia. 2005. Memadu Penelitian Kualitatif dan Kuantitatif. Diterjemahkan oleh H. Nuktah Arfawie Kurde, dkk. dari judul Mixing Methods: Qualitative and Quantitative Reseacrh. Yogyakarta: Pustaka Pelajar.

Chadwick, Bruce A., dkk.. 1991. Metode Penelitian Ilmu Pengetahuan Sosial. Diterjemahkan oleh Sulistia dkk. dari judul Social 
Science Reseacrh Methods. Semarang: IKIP Semarang Press.

Creswell, J. W.. 2012a. Educational Research: Planning, Conducting and Evaluating Quantitative and Qualitative Research. $4^{\text {th }}$ Ed. Boston: Pearson Education.

Creswell, J. W.. 2012b. Research Design: Pendekatan Kualitatif, Kuantitatif, dan Mixed. Diterjemahkan oleh Acmad Fawaid dari judul Research Design: Qualitatif, and Mixed Methods Approaches. Third Edition. Yogyakarta: Pustaka Pelajar.

Darma, Yoce Aliah. 2009. Analisis Wacana Kritis. Bandung: CV Yrama Widya.

Denzin, Norman K. \& Yvona S. Lincoln. 2000. Handbook of Qualitative Research. London: Sage Publication.

Djajasudarma, T. Fatimah. 2006. Wacana: Pemahaman dan Hubungan Antarunsur. Bandung: Refika Aditama.

Eggins, Suzanne. 2004. An Introducing to Systemic Functional Linguistics. London: Continuum.

Emzir. 2010. Metode Penelitian Kualitatif: Analisis Data. Jakarta: PT Raja Grafindo Persada.

Eriyanto, et.al. 2001. Media dan Konflik Etnis. Jakarta: PT Sembrani Aksara Nusantara.
Eriyanto. 2009a. Analisis Framing: Konstruksi, Ideologi, dan Politik Media. Yogyakarta: LKiS.

Eriyanto. 2009b. Analisis Wacana: Pengantar Analisis Teks Media. Yogyakarta: LKiS.

Fakih, Mansour. 2012. Analisis Gender dan Transformasi Sosial. Yogyakarta: Pustaka Pelajar.

Fairclough, Norman. 1989. Language and Power. London: Longman.

Fairclough, Norman. 1995. Media Discourse. London: Edward Arnold.

Fairclough, Norman. 2006. Discourse and Social Changes. Cambridge: Polity Press.

Gee, James Paul. 2011. An Introducing to Discourse analysis. New York: Routledge.

Gustianingsih. 2006. Analisis Wacana pada Media Cetak Perspektif Linguistik Fungsional Sistemik (LFS) dan Pengkajian Representasi Semiotik. Jurnal Ilmiah Bahasa dan Sastra (LOGAT) Vol. II, No. 2:104113.

Halliday, M.A.K. \& Ruqaiya Hasan. 1992. Bahasa, Konteks, dan Teks: Aspek-aspek Bahasa dalam Pandangan Semiotik Sosial. Diterjemahkan oleh Asruddin Barori Tou \& M. Ramlan dari judul Language, Context, and Text: Aspect of Language in a Social-Semiotic Perspective. Yogyakarta: Gadjah Mada University Press. 
Halliday, M.A.K.. 1994. An Introduction to Functional Grammar. London: Arnold.

Halliday, M.A.K. \& Christian M.I.M Matthiessen. 2004. An Introduction to Functional Grammar. London: Arnold.

Ilyas, Yunahar. 2005. Konstruksi Pemikiran Gender dalam Pemikiran Mufasir. Jakarta: Departemen Agama RI.

Imtihani, Najih. 2010. Genre Analysis in The Frame of Systemic Functional Linguistics. Jurnal Humaniora Vol. 22, No. 1:8693.

Jorgensen, Marianne dan Louise Phillips. 2007. Analisis Wacana: Teori dan Metode. Diterjemahkan oleh Abdul Syukur Ibrahim dari Judul Discourse Analyses: Theory and Method. Yogyakarta: Pustaka Pelajar.

Khotimah, Khusnul. 2008. Urgensi Kurikulum Gender dalam Pendidikan. Jurnal Insania: Pemikiran Alternatif Pendidikan, Vol. 13, No. 1: 110.

King, Elizabeth M. dan Andrew D. Mason. 2001. Laporan Penelitian Kebijakan Bank Dunia: Pembangunan Berperspektif Gender Melalui Perspekstif Gender dalam Hak, Sumberdaya, dan Aspirasi. Diterjemahkan oleh T.Marlita dari Judul Engenering Development. Jakarta: Dian Rakyat.

Kusumaningrat, Hikmat dan Purnama Kusumaningrat.

2012.
Jurnalistik: Teori dan Praktik. Bandung: PT Remaja Rosdakarya.

Mahsun. 2007. Edisi Revisi: Metode Penelitian Bahasa: Tahapan Strategi, Metode, dan Tekniknya. Jakarta: PT RajaGrafindo Persada.

Moeleong, Lexy J.. 2007. Metodelogi Penelitian Kualitatif. Bandung: PT Remaja Rosdakarya.

Miles, Matthew B. Dan A. Michael Huberman.1992. Analisis Data Kualitatif: Buku Sumber tentang Metode-metode Baru. Diterjemahkan oleh Tjejep Rohendi R. Jakarta: UI-Press.

Muhammad. 2011. Metode Penelitian Bahasa. Yogyakarta: ArRuzzmedia.

Nugroho, Riant. 2008. Gender dan Administrasi Publik: Studi tentang Kualitas Kesetaraan Gender dalam Administrasi Publik Indonesia Pasca Reformasi 1998-2002. Yogyakarta: Pustaka Pelajar.

Piliang, Yasraf Amir. 2010. Semiotika dan Hipersemiotika: Kode, Gaya \& Matinya Makna. Bandung: Matahari.

Ratna, Nyoman Kutha. 2012. Metodologi Penelitian: Kajian Budaya dan Ilmu Sosial Humaniora pada Umumnya. Yogyakarta: Pustaka Pelajar.

Renkema, Jan. 2004. Introducing to Discourse Studies. Amsterdam: John Bejamin Publishing Company. 
Saragih, A. 2006. Bahasa dalam Konteks Sosial: Pendekatan Linguistik Fungsional Sistemik terhadap Tata bahasa dan Wacana. Medan: Pascasarjana Unimed Press.

Samarin, W. 1988. Ilmu Bahasa Lapangan. Seri ILDEP. Yogyakarta: Kanisius.

Santoso, Anang. 2009. Bahasa Perempuan: Sebuah Ideologi Perjuangan. Jakarta: Bumi Aksara.

Schiffrin, Deborah. 2007. Ancangan Kajian Wacana. Diterjemahkan oleh Abdul Syukur Ibrahim dari Unang et.al dari Judul Approaches to Discourse. Yogyakarta: Pustaka Pelajar.

Sobur, Alex. 2009. Teks Media: Suatu Pengantar untuk Analisis Wacana, Analisis Semiotik, dan Analisis Framing. Bandung: PT Rosda Karya.

Syamsuddin dan Vismaia S. Damaianti. 2009. Metode Penelitian Pendidikan Bahasa. Bandung: PT Remaja Rosdakarya Offset.

Tim Penyusun. 1999. Undang-Undang No. 40 tentang Pers. Jakarta: PWI.

Tim Penyusun. 2009. Kerentanan Perempuan Terhadap Kekerasan Ekonomi \& Kekerasan Seksual:Di Rumah Pendidikan dan Lembaga Negara (Catatan KTP tahun 2008). Jakarta: Komnas Anti Kekerasan Terhadap

Perempuan.
Tim Penyusun. 2010. Tak Hanya di Rumah: Pengalaman Perempuan akan Kekerasan di Pusaran Relasi Kekuasaan yang Timpang (Catatan KTP tahun 2009). Jakarta: Komnas Anti Kekerasan Terhadap Perempuan.

Tim Penyusun. 2011. Teror dan Kekerasan Terhadap Perempuan: Hilangnya Kendali Negara (Catatan KTP tahun 2010). Jakarta: Komnas Anti Kekerasan Terhadap Perempuan.

Tim Penyusun. 2012. Stagnasi Sistem Hukum: Menggantung Asa Perempuan Korban, Catatan Kekerasan Terhadap Perempuan (Catatan KTP tahun 2011). Jakarta: Komnas Anti Kekerasan Terhadap Perempuan.

Tim Penyusun. 2013. Korban Berjuang, Republik Bertindak: Mendobrak Stagnasi Sistem Hukum (Catatan KTP tahun 2012). Jakarta: Komnas Anti Kekerasan Terhadap Perempuan.

Titscher, Stefan, dkk.. 2009. Metode Analisis Teks dan Wacana. Diterjemahkan oleh Gazali dkk (Editor Abdul Syukur Ibrahim) dari Judul Methods of Text and Discourse Analysis. Yogyakarta: Pustaka Pelajar.

Van Dijk, Teun A.. 1977. Text and Context: Explorations in the Semanctics and Pragmatics of Discourse. London: Longman.

Van Dijk, Teun A.. 1993. Elite Discourse 
Mabasan, Vol. 8, No. 1, januari-Juni 2014: 48-67

and Rasicm. London: Sage Publication.

Van Dijk, Teun A.. 1998. Ideology: Multidisciplinary Approaches.

London: Sage Publishing. 